\title{
RASIO KEUANGAN : PEMBERIAN OPINI AUDIT GOING CONCERN OLEH AUDITOR \\ (Studi Kasus Pada Perusahaan Manufaktur di BEI)
}

\section{Yuwita Ariessa Pravasanti}

STIE AAS Surakarta

Email: yuwita.akuntansi@gmail.com

\author{
Novica Indriaty \\ Maksi UNS Surakarta
}

\begin{abstract}
Penelitian ini mengharapkan adanya hubungan antara faktor-faktor dari kelangsungan hidup perusahaan terhadap pemberian Opini Audit Going-Concern, yang berdampak pada kelangsungan hidup suatu perusahaan, maka tujuan penelitian adalah untuk menganalisis dan memperoleh bukti empiris tentang pengaruh faktor-faktor dari kelangsungan hidup perusahaan terhadap pemberian Opini Audit Going Concern. Variabel dependen penelitian ini adalah opini audit going concern. Variable independen terdiri atas Current Ratio, Inventory Turnover Ratio, Debt Ratio, dan ROA. Populasi terdiri dari laporan keuangan perusahaan manufaktur yang tercatat di BEI tahun 2010-2012. Sampel dalam penelitian ini diperoleh dengan metode Purpossive Sampling dan digunakan sampel sebanyak 22 perusahaan manufaktur. Metodemetode yang digunakan adalah metode-metode analisis statistik seperti statistik deskriptif dan pegujian data dengan regresi logistik. Dari hasil penelitian, penulis dapat menyimpulkan bahwa hanya satu variabel yang berpengaruh terhadap Opini Audit yaitu Inventory Turnover Ratio, sedangkan variabel lainnya yaitu Current ratio, Debt Ratio dan ROA tidak berpengaruh terhadap penerimaan opini audit going concern.
\end{abstract}

Keyword: Opini audit going Concern, current ratio, inventory turnover ratio, debt ratio dan $R O A$ 


\section{PENDAHULUAN}

Belakangan ini kasus manipulasi laporan keuangan yang dilakukan oleh perusahaan besar kerap kali terjadi sehingga mengakibatkan profesi akuntan publik mendapat banyak kritikan dari berbagai kalangan. Auditor dinilai cukup ikut andil dalam hal itu sehingga menimbulkan banyak pihak yang merasa dirugikan. AICPA (1988) telah mensyaratkan auditor untuk mengemukakan apakah perusahaan akan dapat mempertahankan kelangsungan hidupnya sampai tahun kedepan setelah pelaporan. Auditor tidak bertanggungjawab terhadap kelangsungan hidup perusahaan namun hanya menjadi pertimbangan auditor dalam memberikan opininya.

Opini yang diberikan oleh auditor mempunyai kandungan informasi. Oleh sebab itu, informasi yang ada haruslah mencerminkan suatu keadaan yang sesungguhnya. Informasi yang berkualitas hanya bisa diberikan oleh seorang auditor yang berkualitas juga. Auditor yang memiliki spesialis pada industri tertentu pasti akan mempunyai pemahaman dan pengetahuan yang lebih baik mengenai kondisi lingkungan industri tersebut. Namun pada kenyataannya, sesuai dengan yang diteliti Mirna dan Indira (2007) menemukan bahwa kualitas audit yang diproksi dengan auditor spesialis tidaklah mempengaruhi pemberian opini audit going concern.

Opini audit going concern selain dipengaruhi informasi financial dan kualitas auditor juga perlu mempertimbangkan informasi non financial seperti karakteristik kepemilikan perusahaan (manajerial dan institusional), dengan adanya kepemilikan tersebut diharapkan keputusan yang diambil merupakan keputusan perusahaan. Dengan demikian perusahaan akan terhindar dari potensi terjadinya kesulitan keuangan. Semakin besar kepemilikan institusional dan manjerial, maka semakin efisien pemanfaatan keuangan perusahaan.

Going concern merupakan asumsi dalam pelaporan keuangan suatu entitas dimana jika suatu entitas mengalami kondisi yang sebaliknya, entitas tersebut menjadi bermasalah (Petronela, 2004). Kajian atas going concern bisa dilakukan dengan melihat kondisi internal sebuah perusahaan yang terkandung pada profitabilitas, likuiditas, ataupun respon investor terhadap perusahaan.

Opini audit going concern berarti merupakan opini yang dikeluarkan auditor untuk memastikan apakah perusahaan dapat mempertahankan kelangsungan hidupnya (SPAP, 2001) dalam Santosa dan Wedari (2007).

Standar Profitabilitas Akuntan Publik (SPAP) dalam Petronela (2004) mengharuskan auditor untuk membuat laporan audit setiap kali auditor mengaudit laporan keuangan. Selain itu, laporan audit hanya dibuat jika audit atas laporan keuangan benar-benar dilakukan. Pernyataan Standar Audit (PSA) No. 30 dalam Petronela (2004) menyatakan bahwa informasi yang secara signifikan dianggap berlawanan dengan asumsi kelangsungan hidup satuan usaha yang berhubungan dengan 
ketidakrnampuan satuan usaha dalam memenuhi kewajiban pada saat jatuh tempo tanpa melakukan penjualan sebagian besar aktiva kepada pihak luar melalui bisnis biasa, restrukturisasi utang, perbaikan operasi yang dipaksakan dari luar dan kegiatan serupa yang lain. Petronela (2004) menyatakan ramalan bahwa suatu perusahaan akan bangkrut atau tidak, termasuk dalam salah satu komponen atas keputusan mengenai going concern. Akibatnya, jika suatu perusahaan dinyatakan dalam kategori bangkrut oleh model keputusan tersebut, ha1 ini akan membantu kepastian dalam opini auditor yang berkaitan dengan kelangsungan hidup suatu bisnis.

\section{Rumusan Masalah}

Adapun rumusan masalah dalam artikel ini adalah "Bagaimana current ratio, inventory turnover ratio, total assets turnover ratio, debt ratio, profit margin on sales dan ROA mempengaruhi auditor dalam memberikan opini audit going concern?"

\section{Tujuan Penelitian}

Berdasarkan rumusan masalah di atas, maka tujuan penelitian ini adalah untuk mengetahui sejauh mana current ratio, inventory turnover ratio, total assets turnover ratio, debt ratio, profit margin on sales dan ROA mempengaruhi auditor dalam memberikan opini audit going concern?

\section{KAJIAN TEORI}

Opini Audit Going Concern
Dilihat sebagai postulat terkait secara eksklusif dengan akuntansi, asumsi kelangsungan usaha mengharuskan manajer untuk menyiapkan laporan keuangan yang dimulai dari premis bahwa perusahaan yang diaudit akan melanjutkan aktivitasnya dalam horizon waktu diprediksi, kecuali kasus ketika manajemen ingin membubarkan perusahaan atau menghentikan aktivitasnya (IASB, 2009 dalam Mironiuc et al.,2012).

Dalam misi audit, auditor keuangan memiliki tanggung jawab untuk mengungkapkan tujuan, independen, dan pendapat profesional atas keakuratan informasi keuangan yang telah dilaporkan dalam kaitannya dengan referensi akuntansi yang dikenakan. Selain itu, auditor harus mempertimbangkan sejauh mana perusahaan yang diaudit dapat melanjutkan aktivitasnya dalam horizon waktu diprediksi, tanpa menjadi bangkrut, yang mempengaruhi akurasi pelaporan. Karena itu, diperlukan untuk menggunakan bukti audit terbaik yang akan mendukung opini audit akhir, yang diperoleh melalui prosedur analitis yang menggunakan metode-metode canggih analisis kuantitatif (Mironiuc et al., 2012).

Arens (1997) dalam Santosa dan Wedari (2007) menyatakan beberapa faktor yang menimbulkan ketidakpastian mengenai kelangsungan hidup perusahaan adalah :

1. Kerugian usaha yang besar secara berulang atau kekurangan modal kerja

2. Ketidakmampuan perusahaan untuk membayar kewajibannya pada saat jatuh tempo dalam jangka pendek 
3. Kehilangan pelanggan utama, terjadinya bencana yang tidak diasuransikan seperti gempa bumi atau banjir atau masalah perburuhan yang tidak biasa

4. Perkara pengadilan, gugatan hukum atau masalah serupa yang sudah terjadi yang dapat membahayakan kemampuan perusahaan untuk beroperasi

Menurut Mutchler (1984), opini audit Going-Concern berpengaruh tetapi tidak secara positif terhadap kelangsungan hidup perusahaan, karena banyak dari auditor itu sendiri tidak setuju terhadap peraturan audit yang ada. Variabel-variabel yang digunakan oleh Mutchler adalah Problem Company, Going-Concern Audit Report,Recipent, dan Ration Banking. Hasil ini diperkuat dengan penelitian yang dilakukan oleh Geiger et.al.(2005) dalam Andika (2007), dimana opini audit GoingConcern tidak terlalu mempengaruhi secara signifikan terhadap kebangkrutan suatu perusahaan, sehingga auditor harus menggunakan seluruh kemampuannya untuk memodifikasi faktor - faktor yang dapat menyebabkan kebangkrutan. Akan tetapi variabel yang digunakan oleh Geiger et.al.(2005) dalam Andika (2007) berbeda dengan yang digunakan oleh Mutchler, yaitu Audit Opinion Going-Concern, Audit Opinion Going-Concern Modified, dan Bankruptcy.

Lain halnya dengan penelitian yang dilakukan Bruynseels dan Willekens (2006) menyelidiki apakah tindakan strategis yang diambil oleh perusahaan-perusahaan yang mengalami kesulitan keuangan akan mempengaruhi keputusan-concernopinion auditor mereka. Hipotesa hubungan antara tindakan strategis klien dan opini audit going concern dapat termotivasi oleh setidaknya dua fitur. Pertama, SAS no. 59 secara eksplisit mengatur pertimbangan masalah non-keuangan (internal dan eksternal) yang bertentangan dan rencana pengelolaan yang meringankan dalam pengambilan keputusan going concern. Oleh karena itu serangkaian luas peristiwa, tindakan dan rencana pengelolaan, termasuk strategis, merupakan penentu potensi keputusan opini going concern. Kedua, perubahan dalam metodologi audit dan teknologi terhadap audit risiko bisnis pendekatan dalam paruh kedua tahun sembilan puluhan (seperti, misalnya, strategis-sistem audit seperti yang diperkenalkan oleh Bell et al. 1997) lebih memotivasi kemungkinan bahwa tindakan strategis dan rencana akan mempengaruhi pengambilan keputusan auditor. Lanjutnya, salah satu aspek yang paling inovatif dari audit risiko bisnis telah menjadi penilaian klien terhadap kelangsungan hidup strategis, yang dapat memiliki dampak besar pada prosedur audit selanjutnya yang direncanakan dan dilaksanakan, dan akibatnya kemungkinan akan mempengaruhi penilaian kelayakan keuangan masa depan klien dan dengan demikian juga dengan keputusan opini going concern.

Menurut Bruynseels dan Willekens (2006), auditor membuat keputusan going concern berdasarkan hasil keuangan yang dilaporkan dan sesuai dengan kewajiban keuangan. Pentingnya informasi selain yang 
terkandung dalam laporan keuangan juga ditekankan dalam SAS no. 59. Selain adanya kecenderungan negatif keuangan dan indikasi lainnya tentang kemungkinan kesulitan keuangan, seperti misalnya default pada perjanjian pinjaman, SAS No 59 juga mendefinisikan masalah internal (nonfinansial) tertentu dan masalah eksternal sebagai kondisi dan peristiwa yang mungkin menunjukkan bahwa akan ada ketidakpastian yang signifikan mengenai entitas untuk melanjutkan going concern. Selanjutnya, SAS No.59 juga mengharuskan auditor untuk mempertimbangkan rencana manajemen untuk mengurangi dampak dari kondisi buruk atau kejadian ketika menilai kemampuan klien mereka untuk melanjutkan going concern. Meskipun pentingnya rencana manajemen strategis diakui dalam praktek audit saat ini, penelitian mengenai dampak dari rencana pengelolaan ke depan pada keputusan going concern sangat sedikit.

Konsep going concern adalah salah satu asumsi dasar dalam akuntansi dan dasar penting dari banyak klasifikasi akuntansi didasarkan pada itu. Salah satu metode tingkatan dalam kaitannya dengan konsep going concern adalah menerapkan rasio keuangan yang dikombinasikan (Salehi, 2009).

\section{Rasio-Rasio Keuangan}

\section{a) Likuiditas}

Aktiva likuid (liquid asset) adalah aktiva yang diperdangangkan dalam suatu pasar yang aktif sehingga akibatnya dapat dengan cepat diubah menjadi kas dengan menggunakan harga pasar yang berlaku, dan posisi likuiditas sebuah perusahaan akan berhubungan dengan pertanyaan ini : Apakah perusahaan akan dapat melunasi utang-utangnya pada saat jatuh tempo dalam waktu satu atau beberapa tahun kemudian? (Brigham dan Houston, 2009). Salah satu rasio likuiditas yang sering digunakan adalah current ratio (Rasio Lancar). Current ratio adalah salah satu ukuran kinerja keuangan yang digunakan untuk menilai likuiditas perusahaan dan kemampuannya atau utang jangka pendeknya (Krismiaji dan Aryani, 2011). Dalam hubungannya dengan likuiditas, semakin kecil current ratio, perusahaan kurang likuid sehingga tidak dapat membayar para krediturnya, maka auditor kemungkinan akan memberikan opini audit dengan going concern (Susanto, 2009).

Rumus :

\section{CurrentRatio}

$$
=\frac{\text { current assets }}{\text { current liabilities }}
$$

\section{b) Managemen Aktiva}

Rasio manajemen aktiva (asset management ratio), mengukur seberapa efektif perusahaan 
mengelola aktivanya. Rasio-rasio ini dirancang untuk menjawab pertanyaan berikut ini : Apakah jumlah total dari tiap-tiap jenis aktiva seperti yang dilaporkan di dalam neraca terlihat wajar, terlalu tinggi, atau terlalu rendah jika dibandingkan dengan tingkat penjualan saat ini dan proyeksinya? (Brigham dan Houston, 2009). Rasio yang menganalisis jenis-jenis aktiva yang berbeda tersebut ialah invetory turnover ratio dan total assets turnover ratio. Inventory turnover ratio mengukur kecepatan sebuah bisnis dapat menjual tingkat persediaan rata-rata. Perhitungannya dilakukan dengan membagi harga pokok penjualan dengan tingkat rata-rata saham yang dimiliki. Rasio perputaran aktiva menunjukkan efisiensi dengan asetaset yang digunakan untuk menghasilkan penjualan. Perhitungan dapat dilakukan dengan menggunakan aset tetap atau total aset.

Rumus :

Inventory turnover ratio

$$
=\frac{\text { sales }}{\text { inventories }}
$$

\section{c) Manajemen Hutang}

Seberapa jauh sebuah perusahaan menggunakan pendanaan melalui hutang atau pengungkit hutang (financial leverage). Menurut (Brigham dan Houston, 2009), leverage memiliki tiga implikasi penting yaitu :

- Dengan memperoleh dana melalu utang, para pemegang saham dapat mempertahankan kendali mereka atas perusahaan tersebut dengan sekaligus membatasi investasi yang mereka berikan

- Kreditor akan melihat pada ekuitas atau dana yang diperoleh sendiri sebagai suatu batasan keamanan sehingga semakin tinggi proporsi dari jumlah modal yang diberikan oleh pemegang saham maka semakin kecil resiko yang harus dihadapi oleh kreditor

- Jika suatu perusahaan mendapatkan hasil dari investasi yang didanai dengan dana hasil pinjaman lebih besar daripada bunga yang dibayarkan maka pengembalian dari modal pemilik akan diperbesar atau diungkit (leveraged).

Salah satu rasio manajemen hutang adalah debt ratio (rasio hutang) yang akan mengukur persentase dari dana yang diberikan oleh para kreditor, dengan rumus :

$$
\text { Debt ratio }=\frac{\text { totalliabilities }}{\text { totalasset }}
$$




\section{d) Profitabilitas}

Profitabilitas adalah hasil akhir dari sejumlah kebijakan dan keputusan yang dilakukan oleh perusahaan. Rasio profitabilitas akan menunjukkan kombinasi efek dari likuiditas, manajemen aktiva dan utang pada hasil-hasil operasi (Brigham dan Houston, 2009). ROA merupakan rasio profitabilitas yang mengukur tingkat laba bersih yang dihasilkan dari penggunaan aset (Krismiaji dan Aryani, 2011). Pada profit margin on sales, laba bersih setelah pajak (EAT) ditunjukkan sebagai persentase dari penjualan. Perhitungan ini memberikan 'bottom line' pada penjualan dan berguna dalam perencanaan laba. Tingkat laba bersih pada penjualan menunjukkan efisiensi dengan biaya operasi yang dikendalikan, dan ini ukuran kinerja manajemen.

$$
R O A=\frac{E A T}{\text { totalasset }}
$$

\section{METODE PENELITIAN}

\section{Populasi dan Sampling}

Populasi yang digunakan dalam penelitian ini adalah laporan keuangan perusahaan manufaktur yang tercatat di Bursa Efek Indonesia (BEI) tahun 2010 sampai 2012. Sampel dalam penelitian ini diperoleh dengan metode Purpossive Samplingdengan kriteria sebagai berikut:
1) Auditee sudah terdaftar di Bursa Efek Indonesia (BEI) 1 Januari 20102012

2) Auditee tidak keluar (delisting) di Bursa Efek Indonesia selama periode penelitian (2010-2012)

3) Menerbitkan laporan keuangan yang telah diaudit oleh auditor independen selama tahun 2010-2012

4) Nilai nominal pada laporan keuangan dinyatakan dalam rupiah (mata uang Indonesia)

Berdasarkan kriteria tersebut, penulis menggunakan sampel sebanyak 22 perusahaan manufaktur pada masing-masing periode sehingga total sampel berjumlah 66 sampel.

\section{Jenis dan Sumber Data}

Data yang diperlukan dalam penelitian ini adalah data sekunder. Data sekunder diperoleh dari laporan keuangan auditan perusahaan manufaktur yang terdaftar di BEI pada tahun 2010-2012 yang telah dipublikasikan.

Teknik Analisis Data

Analisa data yang digunakan dalam penelitian ini melalui tahap-tahap sebagai berikut :

1. Menghitung rasio likuiditas perusahaan

2. Menghitung rasio manajemen aktiva perusahaan

3. Menghitung rasio manajemen hutang perusahaan

4. Menghitung rasio profitabilitas perusahaan 


\section{HASIL PENELITIAN}

\section{Statistics Descriptif}

Statistics Descriptif yang dipakai untuk mengolah data adalah mean, mininum, maksimum dan standar deviasi, yang dihitung dari tiap-tiap rasio yang diuji oleh penulis yang terdiri dari Current Ratio, Inventory Turnover Ratio, Debt Ratio dan Return On Asset (ROA). Pengujian tersebut dilakukan terhadap perusahaan manufaktur dengan jumlah 66 sampel yang diambil dari 22 perusahaan selama periode 2010-2012.

Descriptive Statistics

\begin{tabular}{|c|c|c|c|c|c|}
\hline & $\mathrm{N}$ & $\begin{array}{l}\text { Minimu } \\
\text { m }\end{array}$ & $\begin{array}{l}\text { Maximu } \\
\text { m }\end{array}$ & Mean & $\begin{array}{l}\text { Std. } \\
\text { Deviation }\end{array}$ \\
\hline $\mathrm{CR}$ & 66 & ,584 & 9,441 & 2,79741 & 2,326824 \\
\hline ITR & 66 & 1,637 & 53,705 & 9,48746 & 9,275774 \\
\hline DR & 66 &, 123 & ,805 & ,41038 & ,185708 \\
\hline ROA & 66 & ,001 & ,320 & ,08521 & 065243 \\
\hline Opini & 66 & 0 & 1 & ,32 & ,469 \\
\hline $\begin{array}{ll}\text { Valid } & \mathrm{N} \\
\text { (listwise) } & \end{array}$ & & & & & \\
\hline
\end{tabular}

Tabel diatas menunjukkan statistik deskriptif variabel penelitian penerimaan opiniaudit going concern memiliki rata rata sebesar 0,32; dengan nilai minimum sebesar Odan maksimum sebesar 1 karena merupakan variabel dummy. Standar deviasi untukvariabel ini sebesar 0,469, hal ini dapat diartikan bahwa penyimpangan untuk variabel inisebesar 0,469.

Current Ratio (CR) memiliki ratarata sebesar 2,79741; dengan nilai minimumsebesar 0,584 dan maksimum sebesar 0,9441. Standar deviasi untuk variabel ini sebesar 2,3236824, hal ini dapat diartikan bahwa penyimpangan untuk variabel ini sebesar 2,3236824.

Inventory Turnover Ratio (ITR) memiliki rata - rata sebesar 9,48746; dengan nilai minimum sebesar 1,637 dan maksimum sebesar 53,705. Standar deviasi untuk variabel ini sebesar 9,275774, hal ini dapat diartikan bahwa penyimpangan untuk variabel ini sebesar 9,275774.

Debt Ratio (DR) memiliki rata - rata sebesar 0,41038; dengan nilai minimum sebesar 0,123 dan maksimum sebesar 0,805. Standar deviasi untuk variabel ini sebesar 0,185708,hal ini dapat diartikan bahwa penyimpangan untuk variabel ini sebesar 0,185708 .

Return on asset (ROA) memiliki rata - rata sebesar 0,8521; dengan nilai minimum sebesar 0,001, maksimum sebesar 0,320 dan standar deviasi sebesar 0,65243, hal ini dapat diartikan bahwapenyimpangan untuk variabel ini sebesar 0,65243 . 


\section{Pengujian Hipotesis}

Dalam penelitian ini, uji hipotesis menggunakan Regresi Logistik dan tidak diperlukan adanya uji asumsi klasik.
Penelitian dilakukan dalam periode 20102012 dengan jumlah sample sebanyak 66 sampel.

Variables in the Equation

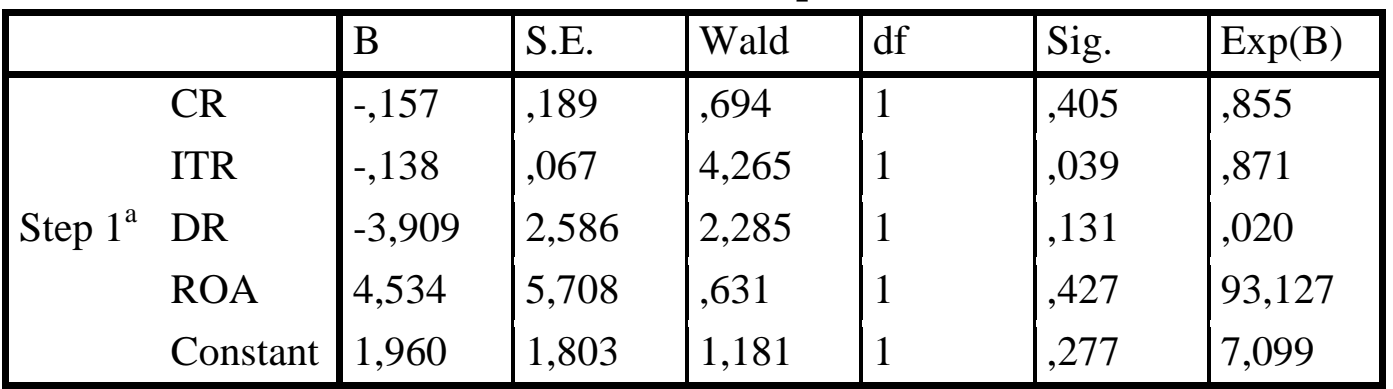

a. Variable(s) entered on step 1: CR, ITR, DR, ROA.

Dari pengujian dengan regresi logistik di atas maka diperoleh persamaan regresi logistik sebagai berikut:

\section{GC $=1.960-0,157$ CR $-0,138$ ITR - 3,909 DR + 4,534 ROA + e}

Dari tabel di atas menunjukkan bahwa variabel Current Ratio menunjukkan nilai koefisien negatif sebesar 0,157 dengan tingkat signifikansi sebesar 0,405 yang lebih besar dari 0,05 (5\%). Artinya dapat disimpulkan bahwa current ratio tidak berpengaruh terhadap penerimaan opini going concern. Jadi, hubungan current ratio dengan opini audit adalah semakin kecil current ratio maka kemampuan perusahaan dalam membayar kewajiban jangka pendeknya semakin lambat sehingga ada keraguan mengenai going concern perusahaan. Berdasarkan survei yang dilakukan terhadap 22 perusahaan manufaktur banyak ditemukan bahwa kewajiban lancar perusahaan rata-rata lebih cepat meningkat dibandingkan dengan aktiva lancarnya.
Variabel Inventory Turnover Ratio menunjukkan nilai koefisien negatif menunjukkan nilai koefisien negatif sebesar 0,318 dengan tingkat signifikansi sebesar 0,039 lebih kecil dari 0,05 (5\%). Artinya dapat disimpulkan bahwa inventory turnover berpengaruh terhadap penerimaan opini going concern. Inventory turnover berpengaruh terhadap penerimaan opini audit going concern karena inventory turnover akan mempengaruhi perolehan keuntungan perusahaan karena jika terjadi kelebihan persediaan menunjukkan bahwa perusahaan tersebut tidak produktif dan mencerimkan suatu investasi dengan tingkat pengembalian yang rendah atau nihil dan tentunya ini akan mempengaruhi going concern suatu perusahaan.

Variabel Debt Ratio menunjukkan nilai koefisien negatif sebesar 0,3909 dengan tingkat signifikansi sebesar 0,131 lebih besar dari 0,05 (5\%). Artinya dapat disimpulkan bahwa debt ratio tidak berpengaruh terhadap penerimaan opini 
going concern. Semakin rendah debt ratio maka semakin besar peredaman dari kerugian yang dialami kreditor jika terjadi likuidasi namun di lain pihak, pemegang saham akan menginginkan lebih banyak leverage karena akan memperbesar ekspektasi keuntungan. Jika debt ratio perusahaan melebihi rata-rata industri ini akan mengakibatkan para kreditor enggan meminjamkan lebih banyak uang dan jika manajemen tetap meningkatkan rasio utang dengan meminjam tambahan dana tentunya ini akan meragukan going concern perusahaan.

Variabel ROA menunjukkan nilai koefisien positif sebesar 4,534 dengan tingkat signifikansi sebesar 0,427 lebih besar dari 0,05 (5\%). Artinya dapat disimpulkan bahwa ROA tidak berpengaruh terhadap penerimaan opini going concern. Jadi, hubungan ROA dengan opini audit adalah semakin kecil ROA maka kemampuan perusahaan dalam mendapatkan laba semakin menurun sehingga ada keraguan mengenai going concern perusahaan.

\section{KESIMPULAN}

Dari hasil penelitian, penulis dapat dapat menyimpulkan bahwa hanya satu variabel yang berpengaruh terhadap Opini Audit yaitu Inventory Turnover Ratio, sedangkan variabel lainnya yaitu Current ratio, Debt Ratio dan ROA tidak berpengaruh terhadap penerimaan opini audit going concern.

\section{Keterbatasan}

Beberapa keterbatasan yang dihadapi penulis dalam penelitian ini antara lain:

- Keterbatasan dari laporan keuangan yang digunakan yaitu hanya meliputi 3 tahun dari 20102012.

- Penelitian hanya menggunakan empat variabel, masing-masing satu rasio sebagai tolok ukur dari likuiditas, manajemen aktiva, manajemen hutang dan profitabilitas pada perusahaan manufaktur.

- Jumlah sampel yang digunakan terlalu sedikit (sebanyak 66 sampel)

\section{Saran}

Beberapa saran yang dapat diberikan untuk penelitian ini adalah:

- Penelitian selanjutnya hendaknya menambahkan jumlah sampel sehingga sampel yang digunakan dapat mewakili semua karakteristik dalam populasi.

- Penelitian berikutnya bisa menambahkan variabel seperti rasio keuangan yang lain, kualitas auditor, ukuran perusahaan dan lain-lain sehingga hasil penelitian lebih memadai.

- Tahun pengamatan diperpanjang supaya bisa melihat kecenderungan trend penerbitan 
Rasio Keuangan : Pemberian Opini

Audit Going Concern Oleh Auditor

ISSN : 1412-

629X

opini audit going concern dalam jangka panjang.

\section{DAFTAR PUSTAKA}

Andika, Arditya Dian. 2007. Pengaruh Struktur Corporate Governance Dan Faktor Kelangsungan Hidup Perusahaan Terhadap Pemberian Opini Audit Going-Concern (Studi Kasus Pada Kantor Akuntan Publik Seluruh Kota Semarang). Universitas Diponegoro

Brigram, Eugene F dan Houston, Joel F. 2009. Fundamentals Of Financial Management (Dasar-Dasar Manajemen Keuangan). Jakarta : Salemba Empat

Bruynseels, Liesbeth dan Willekens, Marleen. 2006. Strategic Viability and Going-Concern Audit Opinions. Katholieke Universiteit Leuven. Belgia

Hani, Clearly, dan Mukhlasin. 2003. Going Concern dan Opini Audit. Simposium Nasional Akuntansi VI. Surabaya

Krismiaji dan Aryani, Y. Anni. 2011. Akuntansi Manajemen. Edisi Kedua. UPP STIM YKPN : Yogyakarta
Mironiuc, Marilena., Robu, Ioan-Bogdan dan Carp, Mihai. 2012. Obtaining Audit Evidence for Assessing Companies' Ability to Continue as a Going Concern, Using Duration Models. Vol. 2012 , Article ID 595761, 21 pages. IBIMA publishing

Mutchler, J.F. 1984. Auditor's Perceptions of Going Concern Opinion Decision. Auditing: A Journal of Practice \& Theory. Spring. Hlm. 17-30.

Petronela, Thio Anastasia. 2004. Pertimbangan Going Concern Perusahaan Dalam Pemberian Opini Audit. Atmajaya

Praptorini, Mirna Dyah dan Indira Januarti. 2007. Analisis Pengaruh Kualitas Auditr, Debt Default dan Opinion Shopping terhadap penerimaan Opini Going Concern. Proceedings Simposium Nasional Akuntansi $X$, UNHAS Makassar, 26-28 Juli, Hlm. 1-27.

Salehi, Mahdi. 2009. Relationship between Going Concern Concept and P/E Ratio in Emerging Market: Case of Iran. Journal of Management Research. ISSN 1941-899X Vol. 1, No. 1: E8 halaman 36-53 
Rasio Keuangan : Pemberian Opini

Audit Going Concern Oleh Auditor

ISSN : 1412-

$629 X$

Santosa, Arga fajar, dan Wedari, Linda Kusumaning. 2007. Analisis factor-faktor yang mempengaruhi kecenderungan penerimaan opini audit going concern. JAII volume 11.No. 2 Hal. 141-158
Susanto, Yulius kurnia. 2009. Faktorfaktor yang mempengaruhi penerimaan opini audit going concern pada perusahaan publik sektor manufaktur. Jurnal bisnis dan akuntansi volume 11 no.3 